
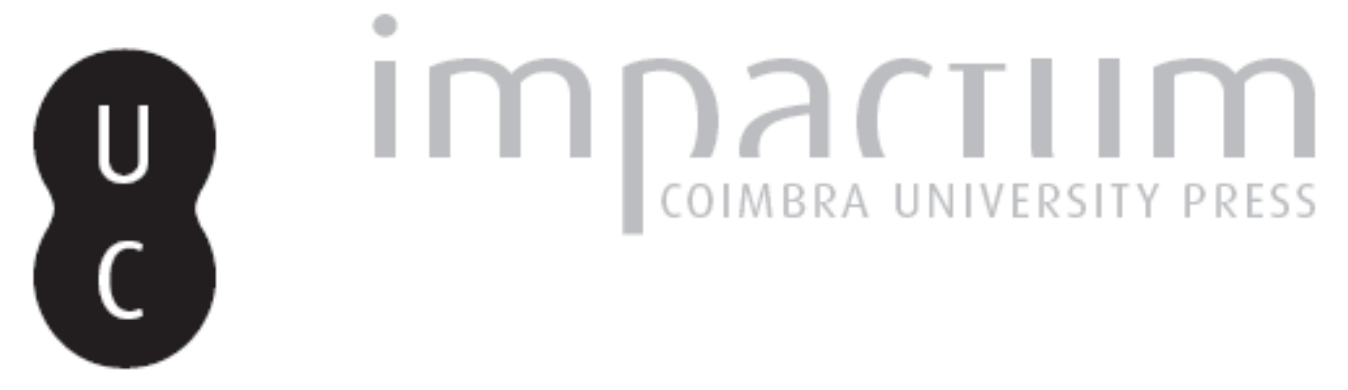

\title{
Annex: Biology, Economics and Crises
}

\author{
Autor(es): [s.n.]
}

Publicado por: Faculdade de Economia da Universidade de Coimbra

URL persistente:

URI:http://hdl.handle.net/10316.2/25240

DOI:

DOI:http://dx.doi.org/10.14195/2183-203X_37_5

Accessed : $\quad$ 26-Apr-2023 12:27:34

A navegação consulta e descarregamento dos títulos inseridos nas Bibliotecas Digitais UC Digitalis, UC Pombalina e UC Impactum, pressupõem a aceitação plena e sem reservas dos Termos e Condições de Uso destas Bibliotecas Digitais, disponíveis em https://digitalis.uc.pt/pt-pt/termos.

Conforme exposto nos referidos Termos e Condições de Uso, o descarregamento de títulos de acesso restrito requer uma licença válida de autorização devendo o utilizador aceder ao(s) documento(s) a partir de um endereço de IP da instituição detentora da supramencionada licença.

Ao utilizador é apenas permitido o descarregamento para uso pessoal, pelo que o emprego do(s) título(s) descarregado(s) para outro fim, designadamente comercial, carece de autorização do respetivo autor ou editor da obra.

Na medida em que todas as obras da UC Digitalis se encontram protegidas pelo Código do Direito de Autor e Direitos Conexos e demais legislação aplicável, toda a cópia, parcial ou total, deste documento, nos casos em que é legalmente admitida, deverá conter ou fazer-se acompanhar por este aviso.

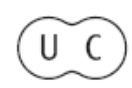




\section{N ○ TASEC O N O MICAS}

$\Delta$

\section{PAUL KRUGMAN'S TRIPLE DOCTORATE}

JORGE BRAGA DE MACEDO

PAUL KRUGMAN JOSÉ SILVA LOPES

ANDRÉ CHAîNEAU

ADÃO CARVALHO

ELSA DE MORAIS SARMENTO/

VANDA DORES /

GUIDA NOGUEIRA

ECONOMISTA MILITANTE

ECONOMICS IN THE CRISIS

COMMENT

LA MONNAIE ET SẸS SINGULARITÉS

FINANCIAMENTO PÚBLICO Ȧ I\&D EMPRESARIAL EM PORTUGAL

A COMPETITIVIDADE E A DIVERSIFICAC,ÃO DA FILEIRA FLORESTAL PORTUGUESA

$\Leftrightarrow$

$\Leftrightarrow$

$(-)$

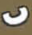

(2)

$\theta$

a

$\theta$ 37

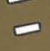
क

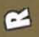
iv 


\section{Annex}

\section{Biology, Economics and Crises}

On 24 February 2012, eight members of the Lisbon Academy of Science, mostly from the economics and finance section (Manuel Jacinto Nunes and Paulo Pitta e Cunha in addition to names starred * below), met to debate Rui Malhó's contribution to an interdisciplinary project promoted by the Academy, NOVASBE's Center for Globalization and Governance and the Tropical Research Institute. The project features a letter to a fictional Portuguese-speaking Queen building on those written by members of the British Academy in response to the famous question about the crisis asked by Queen Elizabeth during her visit to the London School of Economics on 5 November, 2008.

A progress report - titled Writing to Queens as Crises Proceed - was published by IICT in April 2013. It included Malhó's paper, titled «A cell biologist naive approach», a contribution by José Fernando Santos, titled «The role of organization and management in the financial crisis» and abstracts of other contributions by Renato Flores, Jean-Pierre Contzen, etc. The idea underlining the «Letter to Queen Lusofonia», which was absent from the letter to Queen Elizabeth is the hope that Portuguese-speaking economists might transcend the silo curse in a world that is both highly connected and tribal. It remains to be seen whether the diversity of CPLP perspectives could contribute to put multidisciplinary work in the agenda and to trigger public debate by academies and research universities.

Having reiterated Queen Elizabeth's question «Why did people not see the crisis arriving?», Malhó quoted the Hayek vs. Keynes Boom and Bust rap anthem used in Macedo's principles of macroeconomics course at Nova and cautioned against any pretension about what is the best model of economic development as he cannot identify the winner of 'the fight of the century'. Nevertheless, he agrees with Santos and Rui Vilela Mendes, another member of the science class. Before noting «the absolute need to internalize the concept that no system can maintain perpetual expansion/growth» and acknowledging not a mere replacement of dominant powers but the emergence of a «second world» (Parag Khana), he quotes Flores: «as economic policy becomes even more involved with defense and security affairs, the feedbacks from each side to the other seem likely to keep dissent and animosity high, rather than contributing to peaceful and constructive approaches».

For Malhó, biological systems rely on intricate interactions between their players, at both internal and external levels. Whatever decision is taken, it implies enormous risks that may lead to error, which in the vast majority of cases, are dissipated by the system's properties. Conversely, in human societies, the huge pressure that politicians do not error, leads to a lot of subsequent errors. Thus the regulators were too close to the problem to see it. There was cognitive bias and people chose to disregard the high probability that things could go wrong. In addition, the perception of what one thinks is good for him, may not be the really best for him. He added that parallels between biological and society systems are hampered by moral constraints. Solidarity and altruism, which are absent from biological systems, are highly valued in societies, while parasitism and commensalism, driving forces for nature evolution, are morally indefensible. Biological systems do not include bad consciousness, making networking their natural rule. Moving away from equilibrium disturbs the system, forcing it to adjust to a new condition. Societies have less networking than nature. A possible regulation mechanism is to force information networking. However if regulation is too strong it will limit evolution and with sharing of information, assets will be lost. In conclusion, he said that biological and societal systems present similarities in their dealing with crises. In both cases, alternative available resources will be used to satisfy the needs, even if they require more input. In the Portuguese case, an obvious complement to Europe is the Community of Portuguese-speaking Countries (CPLP). 
Mendes responded that problem is the coupling between finance on one side and productive economic activity rather than the crisis itself. In that connection, he emphasized the importance of the timing of intervention from the regulators. Krugman mentioned evolutionary economics. Organisms' evolution occurs locally and takes place over time, maximizing reproductive success, often taking advantage from crises rather than from equilibria. If economics is done with the right spirit, some biological models cannot be applied. Some aspects in economics can instead be modeled by physics.

For Krugman, the Queen's question is the wrong question. Financial crises are not new, they happen all the time and are recognizable. This time is different, but it is never different. At the surface it looks different, but on the basis there is always the same pattern. While this time more documentation is available from the past, people have a short memory regarding crises. In the immediate times people will save, but then they will forget and so will the regulators. People's perception of bank functions has been misjudged. Lots of banks and products were unsupervised and unguaranteed. Krugman also doubted parallels between the biological world and the «human world», he pointed to Greece as a natural catastrophe and raised the question of whether there would be a biological model to solve the crisis.

José Silva Lopes* argued that behavioral economics is a growing field from which we have more to learn than from biology. Sociology and history can give more support to understand and apply to crises: different organisms; different behavior. The way to solve a crisis in Germany can hardly be successfully applied to Portugal, due to personality differences.

Luís Goulão, biologist at IICT, mentioned the contribution of psychology, psychiatry and neurology to understand the crisis, in the framework of the biology of thinking-organisms. Fear prevented us from seeing the crisis and difficulties in facing errors lead to more errors. Different geo-political references induce different information perceptions. Likewise, distinct average life expectancy thrive different decisions and willingness to take risks. Ana Melo, also a biologist at IICT, added that there are two levels of regulation in a cell - locally and globally. There is also an enormous redundancy of regulation mechanisms to overcome cell malfunctioning. Moreover, the efficiency of biological regulation relies on huge networking between every pathway of the system. Only this ensures life as a tightly regulated and thus successful process. Malhó responded that we have to find accurately our place in the system, as there is a difference between individual and collective behavior. Time scale is critical when applying biological models to human behavior because man has social sciences but nature does not.

António Pinto Barbosa* asked Krugman if he would agree that there was some original misdiagnosis about the most relevant fragilities that of the Euro Zone. If so, might have this possibly contributed to a somewhat inadequate design of a proper monetary framework? For Krugman, this crisis was an asymmetric shock story because Europe is pretty close to a closed system.

Helena Garrido, deputy director of Jornal de Negócios, came back to the issue of relating biological models to finance markets: nowadays economy is not the same as a couple of years ago. Can we apply the same models?

At this point, Jorge Braga de Macedo* brought in another Princeton Nobel prize in Economics, Daniel Kahnemann who argues that we have two minds - a shallow and a slow and lazy. Since the second is lazy we tend to use too much of the first, which limits rationality. Therefore, it is easier to see the balances on others than in ourselves. The diversity of CPLP perspectives could contribute to put multidisciplinary work in the agenda and to trigger public debate by academies and research universities. «Portuguese-speaking economists might transcend the silo curse in a world that is both highly connected and tribal».

Krugman doubted again that the «together alone» paradox depicted in Queen Elizabeth's question could trigger a multidisciplinary debate on the global financial crisis or indeed be tackled from a biological approach. As he would say in his lecture and has repeated many times since: 
«No economic theory can perform the feats its users have come to expect of it. (...) Too much of what happens in an economy depends on what people expect to happen.» Through multiple perspectives, sights, networking and capacity of transmission between groups, a new attitude to face and overcome crises arises.

\section{Comment by Rui Vilela Mendes}

As pointed out some time ago by Olivier Blanchard the losses in the subprime loans and securities, a relatively small sector of the US economy, will have a loss impact in the world GDP of at least twenty times more, not to speak of the much larger impact on the world stock market capitalization. This shows the very serious nonlinear coupling of the financial instruments among themselves and with the overall economy.

The financial sector, an otherwise useful device for making capital savings available for investment, has become an independent world by itself with rules and practices sometimes far removed from the realities of the productive economy. Think for example of the volume of oil derivatives traded every day and compare it with the expected production on the next ten years.

Some of the imaginative instruments that are created in the financial world are not even used for its original purpose. For example the pooling of mortgages in MBS's, an adequate instrument of risk transfer, defeat their own purpose when, for reasons of short-time profit, are kept on SIV's. All this is natural to occur, because human ambition is driving the machine and the sector being highly dynamic and innovative is not fully understood by all players. Therefore financial crisis and bubbles are bound to occur and it is unlikely that static regulations will ever avoid them. Many regulations were already in place, which did not control the dot-com bubble or the sub-prime bubble and not probably the next shale-gas bubble.

The strong coupling of the finance world with the world GDP, what is sometimes called the financerization of the economy is the real problem, not crisis which are bound to occur as in any dynamic game. From a useful instrument of the economy, the finance sector became its master. Regulate it, is probably not the right approach. To weaken the coupling would be perhaps better. Is it possible?

\section{Comment and Question by Antonio Pinto Barbosa}

By the time of the creation of the Eurozone (EZ), the most important risk feared was a so called asymmetric shock, illustrated by a fall in demand in some specific member of the union. Conventional thinking emphasized the importance of labor mobility to the subsequent adjustment and, given the low labor mobility in the EZ , the asymmetric shock could set off a protracted recession in that country.

Now, after more than a decade since the launching of the euro, the big threat seems to come from another direction: not so much from an asymmetric demand shock but, instead, 1) from a sort of Minsky moment upon accumulated debts of some member states like Portugal and 2) from the impossibility of the afflicted sovereign state to step into the domestic bond market to cap interest rates, via its Central Bank intervention, when investors are massively pulling out of it. This seems to be, in some sense, the opposite of what the conventional analysis predicted: the big threat came not from insufficient demand caused by some asymmetric shock, but from persistent excess demand above production, an excess translated into a significant accumulation of external debt.

Question: Would you agree that there was some original misdiagnosis about the most relevant fragilities that of the EZ? If so, might have this possibly contributed to a somewhat inadequate design of a proper monetary framework. 